\title{
Social Work Professional Associations in South Africa
}

\author{
Fikile Mazibuko \& Mel Gray
}

Fikile Mazibuko $(\mathrm{PhD})$ is Acting Dean in the Faculty of Community and Development Disciplines (CADD) at the University of Natal, Durban, South Africa where she teaches social policy. She is a welfare policy analysist and instructor who was active in the policy change processes in South Africa.

Mel Gray (PhD) is Professor, Chair and Head of Social Work at the University of Newcastle, New South Wales, Australia and an Honorary Research Professor at the University of Natal, Durban, where she was formerly Professor and Head of the Department of Social Work.

\begin{abstract}
This paper examines the progress of professional associations in South Africa in order to provide an understanding of the current difficulties being experienced in forming one unified body to represent social workers on international organizations, particularly the International Federation of Social Workers (IFSW) to which South Africa is seeking membership. The paper begins with a brief global overview of the development of the social work profession, the role of professional associations and their development in South Africa. It ends with some suggestions as to the way forward if social workers wish to become more visible in policy making processes and thus in influencing the future of welfare in South Africa.
\end{abstract}


The social work profession has its origins in industrialized Europe and North America as attempts were made to respond to the societal needs of the time (Chambers, 1986; Healy 1999; Karger \& Stoesz, 1998; Hugman, 1996; Lyons, 1999). It originated in these Northern regions and soon spread across the Western and Southern nations including South Africa where it followed similar trends. Throughout its existence the profession of social work has tended to focus on the management of dependency brought about by poverty (Popple 1985), on the one hand and on the other, it has involved the protection and promotion of the rights of particular individuals and groups in society (Lyons 1999). In so doing, it has grappled with issues of professionalization, of defining its boundaries and relationship to other professions, and of establishing its own professional identity. It has attempted to respond to diverse needs and social challenges, in the process developing a generalist approach while at the same time promoting increasing specialization within specific fields of practice such as child welfare, aging, disability, mental health, and corrections. The development of social work education was an important part of social work’s professionalization.

The establishment of the first schools of social work in South Africa, at the University of Cape Town in 1924 and the University of Witwatersrand in 1931 (Healy 1999; McKendrick, 1990; Midgley 1999; Rao \& Kendall 1984) coincided with the Hertzog Government's initiative of devising state programs to create work opportunities for indigent and poor white people including white workers in the railways, municipalities and agricultural settlements. In 1924 a government Department of Labour was established primarily for this purpose (McKendrick 1990). These were all initiatives to address poverty and related urbanization issues in the white communities in South Africa. Almost all the schools established during this period were geared towards training personnel 
to respond to poverty and to provide remedial services. It was only in the early 1940s and late 1950s that social work training for other racial groups in the country was introduced.

\section{The development of professional associations}

The development of professional associations was closely related to the advent of social work education in the sense that both institutions functioned as mechanisms where trained professional social workers, including social work educators, could examine and respond effectively to criticism of the social work profession. Some of these criticisms, for example, were that the social work profession was heavily involved in remedial and curative intervention, that it failed to evaluate effectiveness and efficiency, and was not active in policy formulation and social monitoring processes (Bose 1993; Mazibuko, McKendrick \& Patel, 1992; Mazibuko, 1998; Midgley 1996; Popple 1985; Specht 1972). In essence professional associations were determined by and accountable first and foremost to their membership but they also bore a responsibility to those served by the profession. Through professional associations, practitioners and educators worldwide have been able to participate in policy-making processes and influence welfare policy, and promote the interests and advancement of the profession itself. Internationally, organized professional associations are strategically positioned to be part of global activities on social welfare or social work. 


\section{The development of professional associations in South Africa}

Professional associations of social workers in South Africa developed as initiatives through which social workers sought to protect and give voice to their interests within social welfare. In a policy and practice environment fraught with contradictions, it was not surprising that fragmented, racially based, and regional social work formations emerged in line with or as a reaction to apartheid doctrine and policies. With the transition to democracy in the 1990s, the social work profession, and professional associations in particular, were faced with enormous challenges such as the need to redefine their social mission and professional goals within the context of a new developmental welfare policy (White Paper on Social Welfare 1997).

The Social Work Act first promulgated in 1978 when the Council for Social Work was established regulated the social work profession in South Africa. From this time on, social workers were required by law to register for practice. With the transformation of the social work council in the 1990s, a broader Council for Social Service Professions (CSSP) replaced the former Council for Social Work. As later discussion will show, this legislatively constituted body effectively reduced social work's domain within welfare. It is the responsibility of social work (and the related or allied ‘social service professions’ with representation on the CSSP) to develop its own Professional Board for standard setting and professional regulation since there is no written policy on professional associations in South Africa. Thus the onus of establishing a professional organizational structure or national professional association has always and continues to rest with social workers themselves. By way of contrast, the International Federation of Social Workers (IFSW) has a clear policy on its constitution and membership. Only one body can represent the interests of social workers in any one country that seeks membership. The IFSW provides a strategic base for international representation of social work professional associations from across the world and facilitates dialogue between 
social work organisations and professional bodies with related interests (Lyons 1999). The lack of organization within social work in South Africa is currently limiting global professional interaction policy activities and bargaining capability.

\section{Why professional associations?}

Professional associations worldwide promote the interests of social workers and engage in activities that promote the profession so as to give it recognition and standing in the wider community. Professional associations can be viewed as systems that "enhance professional identity, provide opportunities to exchange ideas and encourage professional growth through conferences, publications, newsletters and funding for research. Professional associations also create opportunities for interdisciplinary coalitions and alliances solidifying a united force for policy and legislative advocacy at the local, state and federal levels” (Miley, O’Melia \& du Bois 1998, p.361). To this end, the major functions of professional associations are to:

1. Advance the interests of social workers by attending to matters relating to salaries, service conditions and benefits, and lines of promotion.

2. Promote the professional development of social workers through theory and research, and the introduction of professional journals to facilitate this development.

3. Encourage ethical professional conduct by providing codes of ethics to guide social workers, including practitioners, managers, policy-makers and educators, towards ethically and politically sensitive practice.

4. Ensure the promotion of relevant and appropriate social work education and practice aimed at the alleviation of poverty and the reconstruction and development of communities. 
5. Monitor service provision so as to ensure a just and equitable distribution of social work services.

\section{History of social work professional associations in South Africa}

The history of social work associations mirrors the divided nature of South African society as the following discussion shows. Between the period 1945 and 1995 South Africa witnessed an emergence of at least five professional associations.

\section{South African Black Social Workers Association (SABSWA)}

The South African Black Social Workers' Association came into existence in 1945. SABSWA was established to act as the mouthpiece of black social workers. It made representations to the government and other official bodies on matters concerning social welfare in black communities and ensured that black social workers maintained a high standard of conduct and integrity in accordance with its code of ethics (Mazibuko 1998; Kekana, 1982). SABSWA had a strong community development and community service arm where. Though 'black' was understood to mean persons of Indian, African and mixed descent in South Africa, the membership and program focus of SABSWA was predominantly on African social workers and communities. In its Annual General meeting in 1996 (Resolution 1/96) it deleted black from its name but retained the "B" in its acronym (SABSWA). In October 2000, SABSWA was relaunched with its new mission to focus on human capital development, research and continuing education for its members. The relaunch has not necessarily brought a change in the organizational design and membership composition. 


\section{White Social Worker's Association of South Africa}

The White Social Workers' Association of South Africa began in 1951. It was not only white but also largely Afrikaans. The activities of this association focused on social work as a career, community work in white communities and the professional concerns of its members (Hare 1980; Mazibuko 1998).

\section{Social Work Association of South Africa (SWASA)}

The White Social Workers' Association later became known as SWASA in 1980, in an attempt to remove its racially based focus. During this time with its 'open' membership policy, it focused on educational programs and professional enrichment activities (Hare, 1980; Mazibuko, 1998).

\section{Society for Social Workers of South Africa}

Beginning as a splinter group of the White Social Worker's Association, the Society for Social Workers emerged in 1981 to encourage membership from all race and language groups. However, its members were predominantly white and English speaking. It produced publications that kept its membership informed of current professional developments, which were accessible to social workers generally. During the 1980s it heightened awareness of the plight of children in detention. It ceased its national operation during the 1990s and only its Durban branch remains active with a very small membership.

\section{South African Association of Social Workers in Private Practice (SAASWIPP)}

SAASWIPP is a growing professional organisation of social workers and currently has the largest paid-up membership, estimated to be in the region of 1000 members. As fewer social workers are 
employed in established welfare settings, there is an increasing call for the specialist expertise of social workers in private practice, many of which are contracted by government agencies to render specific services, for example, investigations for the family court.

It is extremely difficult to obtain accurate figures on membership. The authors made an attempt in 1996 when it was established that less than $18 \%$ of social workers registered with the social work council at the time belonged to professional associations. At that time SAASWIPP had the highest paid-up membership of an estimated 1000 social workers, SABSWA had 400 paid-up members though many more with allegiance to this professional body, SWASA had about 100, and the Society for Social Workers still active in Durban had about 60. This yielded a total of 1560 social workers out of a possible 8800 registered with the council with professional affiliation. Thus only a small proportion of social workers in South Africa belong to professional associations. This implies that no one professional association is qualified to represent the interests of South African social workers. At this time it was also ascertained that an estimated 1000 social workers belonged to unions, which seemed to indicate the need for an organisation concerned primarily with labour and workplace issues.

\section{Prior attempts to unite social workers in South Africa}

In the mid and late 1980s it was clear that social workers needed to have a strong unifying body to address and confront issues that were threatening and undermining the profession and thwarting social justice causes and the advancement of human rights. Some of the issues were policy related, such as conditions of service and salaries of social workers. The various associations, together with other loose structures that emerged during this period, such as the Durban Welfare Policy 
Committee, engaged in a ‘unity of action’ strategy (Mazibuko, 1998).

In 1983 the Liaison Committee for Professional Associations was constituted. One of its major goals was to achieve better salaries and working conditions for social workers (Gray 1990; Kekana 1983). This structure received lukewarm support, partly due to suspicion that it was an attempt to gain entry into the IFSW when no agreed upon, recognized structure representing all social workers had yet been established.

In 1989 the Concerned Social Workers group emerged in an effort to address policy and change processes. From time to time it made joint statements and organized protests with other existing professional associations. These included SABSWA, the Society for Social Workers (Johannesburg) and the Durban Welfare Policy Committee. The latter had been established in 1986 by professional and social welfare agencies in and around Durban in protest against the divisive and racially segregated welfare policy proposed by the government in 1985.

These developments indicated that social workers could not rely on splinter groups with different moral and political persuasions if they wished to effectively influence political processes. As Mahaffey (1972) rightfully stated, “political power develops when people are organized, united, and active. Social work organizations should organize their members and be able to mobilize them as necessary” (p. 8). A united professional association that could facilitate the involvement of social workers in political and policy-making processes was even more critical in the South African welfare scenario given that social workers were primarily implementers rather than influencers or formulators of policy. The next movement to unite social workers emerged in 1998 in the form of the Interim Committee for Social Work Associations (ICSWA). 


\section{Interim Committee for Social Work Associations (ICSWA)}

In 1998 a process to unify the divided social work profession began and an Interim Committee for Social Work Associations (ICSWA) was formed. It included SABSWA, SWASA, the Society for Social Workers (Durban), the National Education, Health and Allied Workers Union (NEHAWU), and the Health and Other Services Personnel trade union of South Africa (HOSPERSA). This body was admitted provisionally to the IFSW on condition that one unified body representing all social work associations in South Africa was formed within two years. In 2000 this period was extended for another year by which stage the process had all but broken down and the attempt to launch a KwaZulu-Natal branch of ICSWA had met with a meagre response.

\section{The role of the Council for Social Work}

In retrospect it could be argued that the development of professional social work associations in South Africa was hampered and confounded by the establishment of the Council for Social Work. Not only did some see it as a further attempt by the apartheid government to control the social work profession and its role within welfare, but others saw it as taking over functions which, in other contexts, were the province of professional associations. Perhaps the government did not want social workers to unite across racial divides and pressurize them into changed policies in harmony with the values of the social work profession. Or maybe the divides were so wide that they were impossible to cross at that time given the real divisions created by the apartheid government's homelands policy.

The social work council was a regulatory body that functioned from 1978 - 1992 to protect the interests of the social work profession and its clients by, among other things, determining and maintaining standards of professional conduct and of education for social work. It registered social 
workers, social auxiliary workers and student social workers so that they fell under the ambit of its jurisdiction to protect client interests in the belief that, without recourse to a regulatory body of this nature, gross malpractice would go unchecked. Thus the major functions of the Council for Social Work were to:

1. Advance and protect the interests of the social work profession and its clients.

2. Advise the Minister of Welfare on matters relating to the profession and on national and provincial policies relating to social work.

3. Administer the registration of social workers, social auxiliary workers and student social workers.

4. Determine and maintain standards of professional conduct.

5. Determine and monitor minimum standards for the education and training of social workers.

An examination of the newsletters and reports of the Council from 1982 to 1994 revealed that, from its inception, in addition to the above-mentioned functions, the Council involved itself in the examination of salary and service conditions for social workers. In Newsletter 2 of 1982, it was reported that the Council, together with professional associations, the Minister of Health and Welfare and other state authorities were examining these issues. In 1983 the Council set up a work group to examine the conditions of service for social workers in conjunction with professional associations even though it claimed that this did not fall within the realm of its activities. This was yet another challenge which could have been pursued by a strong professional association.

In 1984 besides being concerned with internal matters such as goals, budget and membership, the Council reported on the Liaison Committee of Professional Associations for Social Workers in South Africa which was instituted in Pretoria on 28 November 1983. At that time, three professional 
associations, namely, SABSWA, SWASA and the Society for Social Workers of South Africa participated in this committee with representatives from the Council.

The third council was in session in 1985. It published Rules relating to unprofessional or improper conduct. In 1986 matters such as professional indemnity insurance, Rules relating to the course of conduct of social workers, which remains South Africa's code of ethics, social workers in private practice, tuition and training in social work, and the promotion of the social work profession all received attention.

The Council again turned its attention to salaries and service conditions for social workers in 1987 when it produced a Draft Framework of Service Conditions for Social Workers (Council for Social and Associated Workers 1987, p. 20-31). The registration of final year social work students was also introduced in that year. In 1988 new rules surrounding unprofessional and improper conduct were compiled and registration of social work students from the second year of study was introduced.

Minimum standards for tuition and training became a major concern of the Council in 1989 when the fourth council was appointed. By 1991 this Council reported on its progress in improving the registration system for social workers, the revision of the rules of conduct, the implementation of new regulations for disciplinary inquiries, finalization of matters pertaining to social auxiliary workers, and an improved indemnity insurance dispensation. Negotiations regarding salaries and service conditions were still ongoing but once again the Council could "say no more and (was) awaiting further developments” (South African Council for Social Work 1991, p. 6).

This brief review of Council newsletters over a period of twelve years, before its transformation into the Interim Council for Social Work, reveals that the Council was mainly concerned with statutory matters. It instituted rules relating to improper or unprofessional conduct, 
introduced indemnity insurance for social workers, the registration of social workers, social work students and social auxiliary workers, and compiled minimum standards for social work education. Salaries and service conditions were a constant theme that continued even after the eventual disbanding of the Liaison Committee. Yet little improvement in the salaries and service conditions for social workers was achieved mainly due to the divided nature of the social work profession and the Council's dubious legitimacy within the apartheid system.

In 1991 there were approximately 6000 registered social workers in South Africa and less than one-sixth belonged to professional associations. The Council for Social Work comprised twelve members of who four were appointed by the government. The remaining eight members were elected by $37 \%$ of registered social workers, six of whom belonged to SWASA with two independent members. Thus it represented a narrow interest grouping of social workers in the country. The Council lacked credibility among black (African) social workers and was never truly representative of South African social workers. Following considerable pressure from SABSWA, the Concerned Social Workers’ Forum and the National Welfare Social Services Development Forum (NWSSDF) it was replaced by an Interim Council for Social Work in 1992 charged with the responsibility of forming a body more representative of all South African social workers.

\section{The role of Unions}

Although accurate numbers are difficult to determine, many black (African) social workers have joined the National Education, Health and Allied Workers' Union (NEHAWU), which was briefly party to discussions around ICSWA and IFSW membership. However, they are no longer part of this process. Some white social workers (mainly Afrikaans speaking) joined HOSPERSA. They too were initially part of the ICSWA process. 


\section{Role and challenges for social workers in $21^{\text {st }}$ century}

\section{The issue of professional unity}

"Unity within the social work profession remains a primary challenge ... (and we) look forward to the day when all involved in the provision of social services speak out with a single powerful voice" (Concerned Social Workers 1989, p. 40-41). This call still resonates today, as the most pressing challenge for social workers in South Africa remains professional unity. Gray (1990) believed that the formation of a professional umbrella body, such as the National Association of Social Workers in the United States of America, could draw social workers together over those matters on which they could agree and promote 'unity in action'. Dspite the ideological differences that divided American social workers, they were able to agree on minimum, basic general principles and interests for the sake of professional unity. Their approach was pragmatic in that ideological differences were not compromised: social workers remained free to support their professional interest groups while at the same time expressing allegiance to a professional bridging or umbrella body. The minimal conditions on which agreement was reached related to definitions of practice and competence, a code of ethics, specialisation, and levels of expertise (Gray 1990).

\section{Engagement with the allied 'social service professions'}

The Council for Social Service Professions established a new regulatory structure which recognized allied occupations as important service providers within welfare, such as child care workers, probation workers and community development workers (Gray 2000). Childcare workers had been sidelined within the previous welfare system and made to play second fiddle to social work. Probation had been a social work role and function from the inception of the welfare system. 
Community development was a fledgling occupation that had long been seen as an important social work method but one which social workers appeared reluctant to pursue, in favour of casework or clinical practice (Gray \& Russell 1989).

Each of these identified so-called 'social service professions' was at a different stage of professional development with social work being the best established. Even though probation had been an important social work function, the implication of the new human resource policy within welfare was that social workers were not doing their job properly and that specialist training in this area was needed. Likewise childcare workers claimed increasing recognition within welfare through implying that social workers were not fulfilling their role within residential child care settings (InterMinisterial Committee for Young People at Risk 1996). These direct criticisms of social work reflected a political process aimed at releasing the stranglehold of existing power cleavages within social work, so as to enforce its transformation. Nowhere was this more evident than in the transformation of the social work council where social workers' disorganization rendered them powerless to withstand the fast tracking of the process, which would severely diminish social work's power within welfare (Gray 2000). The resulting Council for Social Service Professions would have a minimum of 19 members, only six of whom would be social workers with 13 appointed by the Minister of Social Welfare (Gray 1999, 2000). Thus social work’s relationship to the allied 'social service professions' is tied to broader political processes of transformation, to social work's poor image and low status, and to its lack of professional organization.

\section{Conclusion}

In conclusion, while professional associations are an ideal medium to help social workers gain control of their profession and to be involved in decisions affecting their professional practice, they 
have had a chequered history in South Africa. This is due to the deep social and racial divisions engendered by apartheid and attempts by government to control every aspect of social life. The social work profession in South Africa has, as yet, been unsuccessful in drawing together social workers with diverse and seemingly irreconcilable moral and political ideologies. Consequently, it has proved almost impossible to unify the profession and to reach consensus on the tasks and functions of a united professional association (Drower 1991; Gray 1990, 1992).

The authors believe that social workers in South Africa will engage in a number of collaborative and professional relationships for a variety of reasons. It needs to work hard on dispelling the hostile and negative image that it has acquired over the years. One way of dealing effectively with this is to establish a national professional association that will, among other things: 1. Focus on developing a national Code of Ethics.

2. Form alliances with other groups, especially in legislative processes.

3. Formulate opinions, views and positions on developmental social welfare and social work issues of national, continental and international importance.

Collegial relationships are essential and critical in a profession like social work that is diverse, highly specialized and multi-faceted. The profession would be in a stronger position to engage in global social welfare and developmental issues through a national professional association. The splinter professional associations that existed in the $20^{\text {th }}$ century did what they could under divisive and extremely repressive circumstances. Individually, they each had strengths and these could be mobilized to develop a South African national association. From a strength perspective (Rapp, 1998; Saleeby,1996), South Africa is one in modern societies that had a racist system full legitimatised and enforced by the state (Marger, 2000) and was able to enhance ethnicity and multiculturalism into its new doctrine, social policies and delivery structures. In this context, the 
current professional associations had a potential of bringing with them experience and capacity that would contribute to a solid foundation for a common and representative South African professional formation.

Countries, like South Africa, where there is a history of deep division and a rich tapestry of different cultures and religions might learn from this experience and let the past inform the future. No matter how enduring the difficulties, we need to learn to transform the strength of the old into a vibrant new structure for failure to do this will lead to the continued marginalisation of social work with its international face being the voices of the few as it was in the bad old days. Let the dialogue continue for we have no other means to resolve differences. South Africa is also an example of the failure of international social work bodies to influence change and provides a lesson that transformation can only come from within. There is a will and dialogue the only way!

\section{References}

Bose, A.B. (1993). Social Work in India: Development roles for a helping profession. In Hokenstad, M.C.; Khinduka, S.K.; \& Midgley, J. (eds). Profiles in International Social Work. Washington, DC: NASW Press. (71-84)

Brager, G. (1968). Advocacy and political behavior. Social Work, 13(2), 5-15.

Chambers, C.A. (1986). Women in the creation of the profession of social work. Social Service Review, 60(1), 1-33.

Cohen, W. (1966). Social Workers and Political Action. Social Work, 11(3), 3-11.

Council for Social and Associated Workers (1982). Newsletter 2, unpaginated. 
Council for Social and Associated Workers (1987). Draft Framework of Service Conditions for Social Workers, Newsletter 6(1), 20-31.

Drower, S. 1996. Social work values, professional unity and the South African context. Social Work, 41(2), 138-146.

Drower, S.J. (1991). Social work unity: Present quest for the impossible? Social work/ Maatskaplike Werk, 27(1), 36-43.

Gray, M. (2000). Social work and the social service professions. Social Work/Maatskaplike Werk, 36(1), 99-109.

Gray, M. (1999). The marginalisation of social workers in South Africa. Paper presented at the $26^{\text {th }}$ AASW National Conference and Asia-Pacific Regional Conference of IFSW, APASWE \& AASWWE, Brisbane, Australia, September 1999.

Gray, M. (1992). A pragmatic approach to social work unity. Social Work/ Maatskaplike Werk, 28(1), 44-51.

Gray, M. (1990). Social work at the crossroads. Social Work/Maatskaplike Werk, 26(2), 175-179.

Gray, M. \& Collett van Rooyen, C.A.J. (2000). Social work political participation: A South African study. Social Work/Maatskaplike Werk, 36(2), 180-192.

Gray, M. \& Russell, E. (1988). The contribution of social work to social development. Paper presented at the 24th International Congress of Schools of Social Work, Vienna, Austria, July, 1988.

Hare, I.R. (1980). Professional associations of social work in the Republic of South Africa. Special Report to the President of the IFSW. Washington DC: NASW. (December) 
Healy, L. (1999). International Social Work Curriculum in Historical Perspective. In C.S. Ramanathan \& R.J. Link. All our Future: Principles and resources for social work practice in a global era. Boston: Brooks/Cole. 14-29.

Hugman, R. (1996). Professionalization in social work: The challenge of diversity. International Social Work, 39(2), 131-147.

Karger, H.J. \& Stoesz, D. (1998). American social welfare policy: A pluralist approach. New York: Longman.

Kekana, S. (1982). SABSWA $37^{\text {th }}$ Annual Conference. Mangaung, Bloemfontein. (3-5 September).

Lyons, K. (1999). International social work: Themes and perspectives. Brookfield, USA: Ashgate Arena.

Mahaffey, M. (1972). Lobbying and social work. Social Work, 17(1), 3-11.

Marger, N.M. (2000). Race and ethnic relations: American and global perspectives. (5 ${ }^{\text {th }}$ edn), United States: Wadsworth: Thomson Learning.

Mazibuko, F.N.M. (1998). Transformation or organised fragmentation: Exploring the way forward with social worker formations. Social Work/Maatskaplike Werk, 34(1), 27-34.

Mazibuko, F.N.M., Mckendrick, B.W. \& Patel, L. (1992). Social Work in South Africa. In M.C. Hokenstad, S. Khinduka, \& J. Midgley (Eds). Profiles in International Social Work. Washington, DC: NASW Press.

McKendrick, B.W. (Ed). (1990). Introduction to Social Work in South Africa. Pretoria: HAUM Tertiary.

Midgley, J. (1996). Involving social work in economic development. International Social Work, 39(1), 13-25. 
Miley, K.K. O'Melia, M. \& DuBois, B.L. (1998). Generalist social work practice: An empowering approach ( $2^{\text {nd }}$ edn), Boston: Allyn \& Bacon.

Ministry for Welfare and Population Development (1997). White Paper for Social Welfare: Principles, guidelines, recommendations, proposed policies and programmes for developmental social welfare in South Africa. Pretoria: Government Printers.

Popple, P.R. (1985). The social work profession: A reconceptualization. Social Service Review, 59(4), 560-577.

Rao, V \& Kendall, K.A. (1984). World guide to social work education. Council of Social Work Education.

Rapp, C.A. (1998). The strengths model: Case management with people suffering from severe and persistent mental illness. Oxford: Oxford University Press.

Saleeby, D. (1996). The strengths perspective in social work practice: Extensions and cautions. Social Work, 41(3), 296-305.

South African Black Social Workers Association (1982). 37 ${ }^{\text {th }}$ Annual General Meeting Report, Mangaung, 3-5 September.

South African Black Social Workers Association (1996). Resolution 1/96. Annual General Meeting Report. Johannesburg.

South African Council for Social Work (1991). Newsletter 10(2), 1-12.

Specht, H. (1972). The deprofessionalization of social work. Social Work, 17(2) 3-15.

Wolk, J. (1996). Political activity in social work: A theoretical model of motivation. International Social Work, 39(4), 443- 455. 